\title{
Global Market Entry for Finnish SME eCommerce Companies
}

\author{
Marko Mäki and Tuija Toivola
}

\author{
I Online shopping is quickly becoming a preferred way to shop for consumers \\ around the globe."
}

Scalefast, 2021

\begin{abstract}
The aim of this paper is to contribute to knowledge about the expansion of eCommerce (eCom) operations by small and medium-sized enterprises (SMEs) to global markets. We investigate the literature on eCom and reflect on our experiences working with several Finnish eCom companies and consulting firms to boost their global sales. In addition, one important goal of our study was to acquire knowledge and boost participants' learning of fast-growing digital business models. Our findings show that digital disruption and digitalization in general are driving forces behind eCom growth. The study's conclusions underline the importance of targeted marketing activities, knowledge sharing, and capability building for global eCom operations.
\end{abstract}

\section{Introduction}

Competition in many fields of business today has become global in nature. This trend has been accelerated by the rapid digitalization of markets and communication channels. In the global arena, companies compete in environments that deal with diverse online channel formats, including electronic or eCommerce (eCom), mobile commerce, and social media (Bilgihan et al., 2016). Here we focus on eCom and note the influence of the expansion of eCom and digital channels on companies, and also other parts of society.

The current COVID-19 pandemic situation has accelerated the sales and popularity of eCom around the world. Customers have in some ways radically modified their shopping behavior on digital platforms. In Finland, for example, one can see $60 \%$ growth in eCom sales since the pandemic began (Vilkas, 2020).

ECom growth has been global. In Vietnam, China and India, for example, eCom companies have acquired many new customers, while customers generally have changed their buying behaviours from brick-and-mortar stores to digital platforms (Pantelimon et al., 2020). Logistical challenges and slower global transportation have had some negative effect to this trend, but global
eCom growth has become a reality. Even in current strong eCom growth, there is still a lack of studies addressing the influence of digitalization on the internationalization management of SMEs (see Dethine et al., 2020).

Digitalization, in general, offers companies attractive strategic opportunities (Abaidi, \& Vernette, 2018). For the first time, almost any company can reach global markets with relatively easy to use digital eCommerce technology platforms. The adoption of a Direct-toConsumer (DTC) business model means that a company sells its products directly to consumers without any intermediaries (see CBInsights 2019). This has initiated a market disruption, mainly based on both consumers` digital competence development and digital tools and cloud services development offered to companies, provides many opportunities. Digitalization has influenced both companies and customers by enhancing the digital aspects of their assets, processes and value chains. ECommerce can be defined as a key element of business models operating in global markets, typically with DTC format. In general, the term "business model" describes how company does its business. In other words, a business model is "described as a system of interconnected and interdependent activities that determines the way the company 'does business' with its stakeholders” (Zott \& Amit, 2017). However, e- 


\title{
Global Market Entry for Finnish SME eCommerce Companies
}

\author{
Marko Mäki and Tuija Toivola
}

commerce may also have a narrower meaning, it can be defined as a channel alternative to deliver goods or services to customers. In broader and more general terms, eCommerce represents the economic activity of buying and selling products and services through online platforms (Pantelimon et al., 2020).

New disruptive channel developments like those in digital and mobile channels have recently gained attention. Studies had previously focused on channel related perceived risk (Youn, 2009; Fernández-Sabiote \& Román, 2016; Chiou et al., 2017), information collection, and analytics perspectives. (Aguirre et al., 2016). Companies operating with digital platforms like eCom SMEs seemed to internationalize their operations faster than "traditional" firms. However, very little was known about the internationalising process of e-commerce firms, that is, why and how these firms internationalise and what mechanisms drive the process (Grochal-Brejdak \& Szymura-Tyc, 2018). Our study therefore aimed to contribute to this defined research gap.

Several theoretical models had been previously applied to the adoption of e-commerce in SMEs. These models reflected the influence of internal-, external-, and technological factors on adapting to eCom (SanchezTorres \& Juarez-Acosta, 2019). One eCom benefit for companies is the possibility to internationalise sales. B2C eCom seems to be more complex at the international level than at the national level (Macchion et al., 2017), even though modern eCom platforms, like Shopify, offer a variety of tools and plug-ins for facilitation.

Topics in international business and international marketing have gained much attention among academics in recent decades. Global eCom growth has exploded, yet less discussion has taken place about modern types of international operations, like global eCom. In general, the academic research on onlinebased SMEs using digitalization for internationalization remains sparse (Westerlund, 2020). Moreover, "growth hacking" (,Needleman 2014; Conway \& Hemphill, 2019) has gained very limited interest as a marketing approach among researchers and academics, even though this agile, fast, and experiment-orientated marketing approach has become popular among practitioners, especially in the eCom industry.
In September 2017, Haaga-Helia started a European Union (EU) funded project (eComLab project) to help Finnish eCom SMEs internationalize their eCom operations. The aim of the project was to:

- help businesses expand their eCom operations to global markets in a multi-channel context

- study the development, needs, and aims of small Finnish eCom companies that want to expand and globalize their operations

- acquire knowledge and boost companies' and professionals' learning about fast growing online and digital business models.

Following this research, our aim in this paper is to expand on the pragmatic knowledge of eCom operation possibilities and challenges in the global arena and thus to fill the research gap mentioned. This paper reflects our experiences during the project. It highlights the need for new business competencies and use of digital tools to successfully operate in global eCom markets.

The objectives of the study are to: 1) analyze Finnish eCom SMEs' internationalization readiness, 2) evaluate growth hacking processes in the internationalization of eCom, and 3) highlight the need for new competences in order to succeed in global eCom markets.

\section{Summary of Insights from Literature on Global eCom Markets}

eCom as part of global business models

Business model scalability and internationalization have become a general necessity for SME's due, for example, to the limited size and demand of domestic markets (Westerlund, 2020). Hence, companies must internationalize their operations to grow and develop. Two fundamental explanations or models for international operations can be found in the literature. First, the incremental or stages (Uppsala) model, and second, the rapid or "Born Global"-model (Gulanowski et al., 2018). In addition to those, "digital internationalization" has been defined as a mode for global entry (Hervé et al., 2020). According to Lee and Falahat (2019), in this type of internationalization, firms apply different types of digital technologies, such as ecommerce, big data analytics, internet of things, and others for value creation and building competitive 


\title{
Global Market Entry for Finnish SME eCommerce Companies
}

\author{
Marko Mäki and Tuija Toivola
}

advantage. This internationalization approach pinpoints data, information, and knowledge flows. In this classification, e-commerce is defined as an example of digital internationalization, while in practice, e-commerce offers a platform and business model for global market operations.

Knowledge is a key driver of internationalization (Gulanowski et al., 2018). eCom business models are heavily operated through market and customer knowledge, and market-related data analysis. In other words, the eCom business with its marketing operations should be agile and data-driven. The agility of international marketing is an organizational capability that allows firms to better formulate domestic market approaches, while customizing their existing strategies to approach international markets (Li et al., 2019). In our study, "agility" refers to adopting growth hacking principles in marketing and in eCom business generally.

Similarly, eCom possesses many features that support internationalization activities, like "extended market reach" (Rahayu \& Day, 2017) . However, eCom adoption also has attributes that reduce its expansion among businesses. The lack of support, internal constraints, security issues, internal resistance, and insufficient human and IT resources, have been mentioned as factors that discourage eCom adaptation (Ibid). Nonetheless, eCom constitutes an operational mode that aids in the leapfrog development of SMEs' internationalization (see Saeed et al., 2017). In practical terms, global eCom needs strategies for its mode of operations, together with agile marketing tactics and actions in selected markets.

\section{Mode of eCom Operations}

Companies can enter global markets with eCom in various ways. They can build localized language versions of their domestic eCom shop and conduct market specific activities in order to drive them traffic. Alternatively, companies can build a separate eCom shop for a different target market. Another option that can be used simultaneously or as a separate strategy is to use marketplaces like Amazon or Rakuten. A hybrid mode of international operations that combined brickand-mortar retailers together with online sales has also gained popularity. As a result, managing global operations in diverse markets has become a critical task (Schu et al., 2016).
According to Ghazawneh and Henfridsson (2015), "Marketplaces facilitate the exchange of products and services, the transfer of information and payments, and the creation of economic value for parties such as buyers, sellers, and market intermediaries". Different global markets are dominated by different marketplaces. For example, when entering Russian markets, one option is to use Yandex Markets, which has a strong position in Russia. Rakuten has over 87 million active customers in Japan, and many international brands sell products there. Amazon dominates the U.S. and Canadian markets and is also strong in some other countries.

The development of online marketplaces has been rapid in recent years. One example of this is customers' changing search behavior, which is important because eCom companies get traffic to their sites through customer internet searches. This source of traffic is valuable for companies because customers typically need something when they search for items online. Customer search behavior has been changing, however, and in the U.S.A. now almost $40 \%$ of searches start on Amazon, not on search engines like Google (IRCE, 2018). This creates pressure for eCom businesses regarding their global operations planning.

"Dropshipping" offers another mode to run eCommerce operations on a global scale. In this mode of operations, an eCom company does not have to invest in warehouses, as products are delivered to customers directly from the manufacturers. Advantages of this model include low market entry barriers and instant order processing (Witkowski et al., 2020).

\section{Growth Hacking Approach to eCommerce Internationalization}

SMEs can internationalize their operations at various speeds. Slower internationalizing companies are named "born globals" (Rennie, 1993; Paul \& Rosado-Serrano, 2019). eCom business models offer many ways to internationalize SME businesses so that global markets can be reached in short period of time. "Growth hacking" is a marketing framework where digital marketing tools and platforms are used in domestic or global markets. This marketing approach draws on the explosive growth of marketing technologies (Conway \& Hemphill, 2019), relying on testing, implementing, and measuring various digital marketing tactics and contents fast, and with a relatively small budget. After figuring 


\title{
Global Market Entry for Finnish SME eCommerce Companies
}

\author{
Marko Mäki and Tuija Toivola
}

out which tactics attract most customers, the aim is to automate the digital marketing process (Dow Jones Institutional News, 2014). The growth hacking framework is suitable for eCom SME internationalization, due to its flexibility and ability to change marketing activities and target areas in a short period of time. In general, the faster and better a firm understands a global market, the higher the speed of internationalization for a SME (Neubert, 2018).

\section{Methodology}

In September 2017, Haaga-Helia started an EU funded project to help Finnish eCom SMEs that were seeking to internationalize their eCom operations. Our aim was to start with a small group of companies and to increase this number at a later stage by a few more. However, when we marketed the opportunity for companies to participate in our research, we immediately received enquiries from over 20 companies wishing to expand their online operations to global markets.

In our study, we applied a qualitative approach and used mixed methods to gather and analyze data. We conducted the study following action research principles whereby companies, researchers, and students collaborate closely during the research process (Reason \& Bradbury, 2009). Moreover, we underlined the practical knowledge, results, and actions throughout the research project. Action research, in general, requires researchers to work with practitioners in a way that research and practice can create results together (Lim et al., 2018).

In the first phase, we asked the companies to fill in an online survey, in which they self-evaluated their current eCom status, their knowledge of and experience in global business, and their aims and resources in terms of global eCom operations. The relatively short survey was inspired and derived from Foscht, Swoboda, and Morschett's (2006) line of thinking, where they discussed the potential of small eCom companies to internationalize their operations in a relatively short time period and international market selection.

The main purpose of our survey, however, was pragmatic. The results guided our action research activities and the target market selected. Based on this information, we ended up working with 14 companies. In 2017, we started with a pilot group of four companies, and during 2018, 10 more companies joined in. Additionally, we recruited three eCom consulting companies and two foreign universities. Around 30 Finnish and 40 foreign students took part in the research during various phases of the project.

We subjected the quantitative data collected to frequency analysis. The qualitative data consisted of consulting session memos, target market analysis and other text materials. Consulting session themes were derived per the overall objective of the study. We created a loosely defined type of code list derived from theoretical themes and used it as the basis for qualitative analysis. The main themes relate to eCom operative issues, globalization progress, domestic/global marketing, and growth hacking activities. This kind of approach is generally considered suitable to avoid data overload (Miles \& Huberman, 1994).

The aim of our project was to contribute to the expansion of businesses' eCom operations to global markets in a multi-channel management context. We also wanted to study the development needs and aims of Finnish eCom SMEs that wanted to expand and globalize their operations. In addition, one important goal was to develop knowledge that could boost companies and professionals' knowledge and awareness of fast growing online and digital business models. Thus, our findings and conclusions were based on a starting point analysis, with one-to-one consulting, and common workshops. We were part of the research process, including online survey, consulting sessions and company workshops, right from the planning phase. During this period, we had many discussions with CEOs and other company representatives to understand their experiences and challenges.

\section{Summary of Results}

Our action-based research approach had three phases. First, the project started with a baseline analysis to map participating companies' wishes and wants related to their global eCom development needs. Second, we analyzed summary materials for each participating company based on two consulting workshops. And, third, two participating universities conducted country specific analyses in Russia and in Japan. In Table 2, we summarize the basic information about the companies. 


\title{
Global Market Entry for Finnish SME eCommerce Companies
}

\author{
Marko Mäki and Tuija Toivola
}

Table 1. Qualitative and quantitative data collection during the eComLab project

\begin{tabular}{|c|c|c|}
\hline Study type & Method & Sample/ data \\
\hline Baseline analysis & $\begin{array}{l}\text { Web-based } \\
\text { questionnaire }\end{array}$ & $\begin{array}{l}10 \text { companies } \\
\text { responded }\end{array}$ \\
\hline $\begin{array}{l}\text { One-to-one } \\
\text { consulting process }\end{array}$ & $\begin{array}{l}\text { Participation in growth } \\
\text { hacking activities in } \\
\text { selected countries and } \\
\text { digital marketing } \\
\text { campaigns }\end{array}$ & $\begin{array}{l}14 \text { companies } \\
\text { around } 30 \text { pages of } \\
\text { session summaries }\end{array}$ \\
\hline $\begin{array}{l}\text { Target market } \\
\text { analysis }\end{array}$ & $\begin{array}{l}\text { Mixed student teams, } \\
\text { including local and } \\
\text { native students from } \\
\text { new target markets } \\
\text { St. Petersburg State } \\
\text { University of Economics } \\
\text { (Russia) } \\
\text { Toyo University (Japan) }\end{array}$ & $\begin{array}{l}\text { Three companies } \\
\text { chosen for the } \\
\text { Russian market and } \\
\text { two for the Japanese } \\
\text { market } \\
\text { Altogether } 14 \\
\text { presentations and } \\
100 \text { pages of } \\
\text { reporting material }\end{array}$ \\
\hline $\begin{array}{l}\text { Artificial } \\
\text { Intelligence (AI) in } \\
\text { eCom }\end{array}$ & $\begin{array}{l}\text { Hackathon/designathon } \\
\text { involving teams of } \\
\text { business and } \\
\text { engineering students } \\
\text { Three teams worked for } \\
\text { two days and came up } \\
\text { with new ideas and } \\
\text { concrete solutions }\end{array}$ & $\begin{array}{l}\text { Business partner } \\
\text { Elisa Ltd, a Finnish } \\
\text { telecom company } \\
\text { Hackathon reports }\end{array}$ \\
\hline Workshops & $\begin{array}{l}\text { Sharing experiences } \\
\text { and learning }\end{array}$ & $\begin{array}{l}\text { All teachers, } \\
\text { consultants, } \\
\text { companies, and } \\
\text { university staff }\end{array}$ \\
\hline
\end{tabular}

\section{Summary of insights from baseline analysis}

In the web-questionnaire, in addition to basic facts, we assessed companies' level of internationalization, their technological eCom solutions, and their preferred target markets. All companies were interested in international eCom, and all companies recognised that their markets were global, not local. This outcome was good for our project because in Finland over $80 \%$ of eCom companies operate in only one language, Finnish, meaning that they can only reach the national market in Finland. The technological eCom solutions adapted by companies varied, ranged from international cloud-based platforms, like e-Pages or Shopify, to smaller domestic solutions, like MyCashFlow. Only a few used open-source solutions like WordPress or WooCommerce. According to our analysis and discussions in the development process, all of solutions proposed had pros and cons, but all the platforms enabled companies to successfully launch in global markets.

We also asked participating companies about their most desired global target markets. Countries that belong to the EU, like Germany, were mentioned. We believe that the reason for the popularity of EU markets was the ability of companies to quickly and easily access them without entry barriers or tariffs. Moreover, Russia and Japan were also mentioned as target markets for global entry. Despite sanctions, Russia has a large population in many customer segments. For example, St. Petersburg has the same population as the whole of Finland, with around 5.5 million people. Given its close proximity to Finland, this was an attractive market for many Finnish eCom companies. Japan, on the other hand, has a large population where Finnish natural food companies have gained popularity.

In their starting point analysis, companies evaluated the strongest elements of their online shop, where they most needed help, and what they wanted to develop. Below, we provide a summary of the most common stated strengths and weaknesses by these companies. The main reason for applying to our project was that they lacked resources and competence in online sales and marketing. All of the participating companies had a strong motivation to internationalize and increase their 


\section{Global Market Entry for Finnish SME eCommerce Companies} Marko Mäki and Tuija Toivola

Table 2. Summary of key company facts and starting point analysis

\begin{tabular}{|c|c|c|c|c|c|c|}
\hline Company & Industry & $\begin{array}{l}\text { Number of } \\
\text { language } \\
\text { options in } \\
\text { online shop }\end{array}$ & $\begin{array}{l}\text { Experience } \\
\text { in global } \\
\text { business } \\
\mathrm{Y} / \mathrm{N}\end{array}$ & $\begin{array}{l}\text { Online shop } \\
\text { established }\end{array}$ & $\begin{array}{l}\text { Where are } \\
\text { your } \\
\text { customers at } \\
\text { the moment? }\end{array}$ & $\begin{array}{l}\text { Self- } \\
\text { evaluated } \\
\text { eCom } \\
\text { competence }\end{array}$ \\
\hline $\begin{array}{l}\text { Company } \\
1\end{array}$ & $\begin{array}{l}\text { Consumer } \\
\text { Electronics }\end{array}$ & $3-4$ & Yes & 2011 & Europe & $\begin{array}{l}\text { Basic, lots } \\
\text { to } \\
\text { learn }\end{array}$ \\
\hline $\begin{array}{l}\text { Company } \\
2\end{array}$ & $\begin{array}{l}\text { Production } \\
\text { and selling } \\
\text { of children's } \\
\text { clothes }\end{array}$ & $3-4$ & Yes & 4.5 years & $\begin{array}{l}\text { Europe, } \\
\text { Asia, and } \\
\text { Russia }\end{array}$ & Advanced \\
\hline $\begin{array}{l}\text { Company } \\
3\end{array}$ & $\begin{array}{l}\text { Style and } \\
\text { fashion }\end{array}$ & $3-4$ & No & 2 years & Finland & Basic \\
\hline $\begin{array}{l}\text { Company } \\
4\end{array}$ & Design & 1 & Yes & 3 years & Europe & Basic \\
\hline $\begin{array}{l}\text { Company } \\
5\end{array}$ & Design & 1 & Yes & 5 years & $\begin{array}{l}\text { Europe, } \\
\text { Asia and the } \\
\text { U.S. }\end{array}$ & Basic \\
\hline $\begin{array}{l}\text { Company } \\
6\end{array}$ & $\begin{array}{l}\text { Shoe } \\
\text { production }\end{array}$ & 2 & Yes & 2014 & $\begin{array}{l}\text { Europe, } \\
\text { Russian, USA } \\
\text { and Asia }\end{array}$ & Basic \\
\hline $\begin{array}{l}\text { Company } \\
7\end{array}$ & $\begin{array}{l}\text { Industrial } \\
\text { design }\end{array}$ & 2 & No & 2 years & Europe & Basic \\
\hline $\begin{array}{l}\text { Company } \\
8\end{array}$ & $\begin{array}{l}\text { Mattress } \\
\text { production }\end{array}$ & 2 & Yes & 2018 & Worldwide & Beginner \\
\hline $\begin{array}{l}\text { Company } \\
9\end{array}$ & $\begin{array}{l}\text { Design/ } \\
\text { fashion }\end{array}$ & 1 & Yes & 2017 & Europe & Basic \\
\hline $\begin{array}{l}\text { Company } \\
10\end{array}$ & $\begin{array}{l}\text { Interior } \\
\text { design }\end{array}$ & 1 & Yes & 2015 & Worldwide & Basic \\
\hline
\end{tabular}

global online sales.

\section{Summary of insights from consulting sessions}

Three consulting companies took part in the eComLab project. Of these, two of them specialized in eCom business, with expertise in marketing, general competitiveness, and user interface development. The third consulting company was an expert in eCom entry and managing global marketplaces, like Rakuten (Japan), Amazon (Germany), Yandex Market (Russia), and WeChat (China). Summary and key action points in the consulting sessions of the study are shown in Table 4 .

The marketplace consulting done concentrated first on
Rakuten and Yandex Market. Later, one company wanted to enter Amazon, and five participating companies opened a WeChat account to boost sales in Chinese markets. All participating companies took part in general eCom consulting sessions that aimed to boost sales in international markets.

Companies took part in two consulting sessions. The first session focused on a general evaluation of the strengths and weaknesses of each company's online shop. The second session focused on marketing activities in defined markets and was carried out using growth hacking principles.

The following topics and development areas were 


\title{
Global Market Entry for Finnish SME eCommerce Companies
}

\author{
Marko Mäki and Tuija Toivola
}

Table 3. Companies' perceived strengths and weaknesses for global eCom entry

\begin{tabular}{l|l}
\hline Strengths & Weaknesses \\
\hline Good brand and products & Attracting visitors and increasing sales \\
Customer support in English & Effective online marketing to target market \\
Motivation to grow and develop & Lack of language options in online shop \\
Finnish design and good quality & Insufficient knowledge of customer journey in \\
products & online store \\
& Unknown customer buying behavior in \\
& international target market \\
& Poor mobile optimization of online shop \\
& Lack of analytic tools used and retargeting leads
\end{tabular}

assessed and discussed in the evaluation session: site speed, customer journey, ease of shopping, product card content, level of marketing activities, and user experience in offering products and services via mobile and desktop channels. The main areas identified for development related to mobile and desktop user experience.

"Focus not very clear. Is this a webshop or a catalog? Mobile works well and is even faster than desktop."

"Mobile needs some scrolling and buttons were quite small."

"Always recommended to measure customer journey activities with Hotjar or Lucky Orange."

"Site optimization both in domestic and English sites recommended."

In many cases, the companies' online shops seemed to work well either on desktop or mobile devices, but not on both. Some product cards had very little product information, which negatively affected customer experience. Page speed analyses revealed some problems in page loading speeds. In addition, the companies' found they had an inadequate level of global marketing activities.

"Problems start in latter phases of customer journey ... (the) product card information is not clear and the button has some problems in mobile interface."

"What are the operative plans to internationalize eCom, language versions, or separate shops to target markets?"

"Quite a lot of sales arguments for international markets need $A / B$-testing."

\section{"Domestic payment methods are ok for domestic customers, but do not create trust among international customers. These have to be modified for international audience."}

The consultants recommended that companies increase their marketing activity, especially via Facebook, Instagram, and Google ads. Remarketing or retargeting was not used as much, though it made up one development phase.

"Web shop traffic is at a good level, but retargeting activities in Google Ads, Facebook and in Instagram is recommended."

"You have great product pictures. Now share vertical pictures \& videos in mobile for global customers."

The second consulting session was carried out using growth hacking principles. This meant that rapid marketing activities were implemented, typically using Facebook, Instagram, and Google Ads activities, in a couple of foreign markets. In general, results were achieved and participating companies had an opportunity to sell their product to new markets. The results of this latter growth hacking phase are summarized below.

Key results from the growth hacking sessions:

- Over 300,000 potential clients reached

- Online store visitors via paid traffic from Europe, Asia, and America

- Visitors from more than 10 countries, such as Sweden, Belgium, Germany, Switzerland, Singapore, the U.S.A., and the Netherlands 


\title{
Global Market Entry for Finnish SME eCommerce Companies
}

\author{
Marko Mäki and Tuija Toivola
}

Table 4. Key observations from consulting sessions

\begin{tabular}{|l|l|l|l|}
\hline Consulting topic & Participants & $\begin{array}{l}\text { Aim and length of } \\
\text { consulting }\end{array}$ & Key results \\
\hline $\begin{array}{l}\text { Entering } \\
\text { international } \\
\text { marketplaces }\end{array}$ & $\begin{array}{l}\text { Five (5) } \\
\text { participating } \\
\text { companies }\end{array}$ & $\begin{array}{l}\text { Help companies to } \\
\text { launch their product to } \\
\text { global marketplaces like } \\
\text { Rakuten, Amazon and } \\
\text { Yandex Markets; several } \\
\text { one-to-one sessions }\end{array}$ & One market entry \\
\hline $\begin{array}{l}\text { eCommerce } \\
\text { enalysis, }\end{array}$ & $\begin{array}{l}\text { All (14) } \\
\text { participating } \\
\text { companies }\end{array}$ & $\begin{array}{l}\text { Analysis of company's } \\
\text { eCommerce site; about } \\
\text { 2 hours session }\end{array}$ & Analysis report \\
\hline $\begin{array}{l}\text { eCommerce } \\
\text { marketing in } \\
\text { target market }\end{array}$ & $\begin{array}{l}\text { All (14) } \\
\text { participating } \\
\text { companies }\end{array}$ & $\begin{array}{l}\text { Growth hacking, digital } \\
\text { marketing actions in } \\
\text { target market; length }\end{array}$ & $\begin{array}{l}\text { Customer } \\
\text { acquisition, sales } \\
\text { boost, and } \\
\text { conversion boost }\end{array}$ \\
\hline
\end{tabular}

- Purchases from five to seven different countries

- Single purchases from 6 euros to 500+ euros each

- Average order value was a key variable; it is important to sell more expensive goods with larger orders when selling globally.

The importance of the customer journey analysis was also underlined in the consulting sessions. None of the participating companies had experience with or were using analytic tools like Lucky Orange or Hotjar to acquire knowledge of how customers navigated their online shops. The use of customer journey analytics was strongly recommended.

\section{Conclusions}

This study found new insights in expanding eCom international operations by SMEs. This topic is important because online sales are growing and domestic companies are facing high levels of global competition. All companies, whether they operate in hybrid channels or pure eCom formats, must build their capabilities to operate in a digital and global environment.

The study showed that eCom as a business model has many advantages. In general, the adoption of eCom could allow companies to gain access to new customer segments, develop new markets, and improve their profitability (Macchion et al., 2017). Moreover, increasing capabilities in information technology has a positive effect for a company's internationalization (Lecerf \& Omrani, 2019). By adopting an eCom business model, companies enter a digital learning process, especially if they adopt growth hacking principles in marketing and business development. However, many SMEs struggle to engage in a coherent global digital transformation process (Dethine et al., 2020). This means problems both in technology implementation and skills development.

According to our study, the participating companies initially had quite a limited view about the opportunities eCom could offer them for international expansion. None of the companies we studied had utilized global marketplaces for their internationalization efforts, and only a couple had language versions of their on-line stores for foreign markets. The capabilities these companies had to utilize digital marketing and analytics tool was also quite limited.

According to a recent article (Kaushik et al., 2020), the main challenges faced by online retailers today include providing a superior customer service experience, reducing the perceived risks of online shopping in the mind of consumers, and producing an effective website design. Our findings strengthen the argument that running an eCom business requires solid business, digital marketing, and information and communication technologies (ICT) to expand sales domestically and internationally.

While eCom basics must be delivered, like a smooth 


\title{
Global Market Entry for Finnish SME eCommerce Companies
}

\author{
Marko Mäki and Tuija Toivola
}

mobile device customer experience, our findings show that companies must also pay special attention to marketing activities. This concerns companies that operate in global marketplaces and also those whose aim is to drive traffic directly to their localized online shops. Moreover, in many cases, we were confronted with companies that lacked resources to concentrate on the global dimension of eCom. Companies that do not have the necessary time, knowledge, or capabilities for eCom will likely find global market-related aims difficult to achieve. Our study thus underlines taking active approach to different possibilities that eCom can offer so that SMEs may develop their businesses and scale their international operations. In practical terms, this means learning new skills and adopting available technologies.

Another goal of this study was to increase understanding of the internationalization processes of eCom companies. As mentioned by Grochal-Brejdak and Szymura-Tyc (2018), companies that operate with digital platforms, like eCom SMEs, seem to internationalize their operations faster than traditional companies. By engaging directly with companies attempting to internationalize, our study contributed to closing the gap regarding how these firms internationalize, as well as what mechanisms drive the process. Our findings pinpointed the differences between global market entry modes and strategies inside eCom business models. While growth hacking and other marketing activities resulted in positive commercial results for the companies in our study, marketplace entry activities faced many challenges, especially in Japan and Russia, for the Finnish companies involved. More research is therefore needed to better understand global eCom marketing processes and eCom entry mode characteristics of SMEs.

\section{Acknowledgment}

We would like to thank the European Regional Development Fund for supporting our project. 


\title{
Global Market Entry for Finnish SME eCommerce Companies
}

\author{
Marko Mäki and Tuija Toivola
}

\section{References}

Abaidi, I., \& Vernette, E. 2018. Does digitalization create or reduce perceived global value? The Journal of Consumer Marketing, 35(7): 676-687.

Aguirre, E., Roggeveen, A.L., Grewal, D., \& Wetzels, M. 2016. The personalization- privacy paradox: Implications for new media. The Journal of Consumer Marketing, 33(2): 98-110.

Bilgihan, A., Kandampully, J., \& Zhang, T., 2016. Towards a unified customer experience in online shopping environments. International Journal of Quality and Service Sciences, 8(1): 102-119.

CBInsights. 2019. Retrieved from:

https://www.cbinsights.com/research/direct-toconsumer-retail-strategies/

Chiou, J., Chou, S., \& Shen, G.C. 2017. Consumer choice of multichannel shopping. Internet Research, 27(1): 2-20.

Conway, T., \& Hemphill, T. 2019. Growth hacking as an approach to producing growth amongst UK technology start-ups: An evaluation. Journal of Research in Marketing and Entrepreneurship, 21(2): 163-179. doi:

http://dx.doi.org.ezproxy.haaga-

helia.fi:2048/10.1108/JRME-12-2018-0065

Dethine, B., Enjolras, M., \& Monticolo, D. 2020. Digitalization and SMEs' ExportManagement: Impacts on resources and capabilities. Technology Innovation Management Review, 10(4): 18-34

Fernández-Sabiote, E., \& Román, S. 2016. The multichannel customer's service experience: Building satisfaction and trust. Service Business, 10(2): 423-445.

Foscht, T., Swoboda, B., \& Morschett, D. 2006. Electronic commerce-based internationalisation of small, niche-oriented retailing companies: The case of blue tomato and the snowboard industry. International Journal of Retail \& Distribution Management, 34(7): 556-572.

doi: http://dx.doi.org.ezproxy.haagahelia.fi:2048/10.1108/09590550610673626

Ghazawneh, A., \& Henfridsson, O. 2015. A paradigmatic analysis of digital application marketplaces. Journal of Information Technology, 30(3): 198-208.

Grochal-Brejdak, M., \& Szymura-Tyc, M. 2018. The internationalisation process of an E-commerce entrepreneurial firm: The inward-outward internationalisation and the development of knowledge. Entrepreneurial Business and Economics Review, 6(4): 103.

doi: http://dx.doi.org.ezproxy.haagahelia.fi:2048/10.15678/EBER.2018.060406

Gulanowski, D., Papadopoulos, N., \& Plante, L. 2018. The role of knowledge in international expansion: Toward an integration of competing models of internationalization. Review of International Business and Strategy, 28(1): 35-60. Retrieved from:

https:/ / search-proquest-com.ezproxy.haaga-

helia.fi/scholarly-journals/role-knowledge-

international-expansion/docview/2011327491/se-

2 ? accountid $=27436$

Hervé, A., Schmitt, C., \& Baldegger, R. 2020. Internationalization and digitalization: Applying digital technologies to the internationalization process of small and medium-sized enterprises. Technology Innovation Management Review, 10(7): 28-40.

DOI: http://doi.org/10.22215/timreview/1373

Internet Retail Conference (IRCE). 2018. Chicago, USA. Keynote memo.

Kaushik, V., Khare, A., Boardman, R., \& Cano, M.B. 2020. Why do online retailers succeed? The identification and prioritization of success factors for Indian fashion retailers. Electronic Commerce Research \& Applications, 39, N.PAG.

https://doi-org.ezproxy.haaga-

helia.fi/10.1016/j.elerap.2019.100906

Lecerf, M., \& Omrani, N. 2019. Internationalization: The impact of information technology and innovation. Journal of the Knowledge Economy.

Lee, Y.Y., \& Falahat, M. 2019. The impact of digitalization and resources on gaining competitive advantage in international markets: The mediating role of marketing, innovation and learning capabilities. Technology Innovation Management Review, 9(11): 26-38.

DOI: http://doi.org/10.22215/timreview/1281

Li, R., Liu, Y., \& Bustinza, O.F. 2019. FDI, service intensity, and international marketing agility. International Marketing Review, 36(2): 213-238.

doi: $\quad$ http://dx.doi.org.ezproxy.haagahelia.fi:2048/10.1108/IMR-01-2018-0031

Lim, C., Min-Jun, K., Ki-Hun, K., Kwang-Jae, K., \& Maglio, P.P. 2018. Using data to advance service: Managerial issues and theoretical implications from action research. Journal of Service Theory and Practice, 28(1): 99-128.

Macchion, L., Moretto, A.M., Caniato, F., Caridi, M., Danese, P., \& Vinelli, A. 2017. International ecommerce for fashion products: What is the relationship with performance? International Journal of Retail \& Distribution Management, 45(9): 10111031.

Miles, M.B. \& Huberman, A. 1994. Qualitative Data Analysis: An Expanded Source Book, 2nd ed. New York, Sage Publications.

Needleman, Sarah E. 2014. 'Growth hacking' helps startups boost their users. Dow Jones Institutional News. Retrieved from https://search-proquest-com.ezproxy.haagahelia.fi/docview/2077167855 ?accountid=27436

Neubert, M. 2018. The impact of digitalization on the 


\title{
Global Market Entry for Finnish SME eCommerce Companies
}

\author{
Marko Mäki and Tuija Toivola
}

speed of internationalization of lean global startups. Technology Innovation Management Review, 8(5), 4454.

DOI: http://doi.org/10.22215/timreview/1158

Pantelimon, F., Georgescu, T., \& Posedaru, B. 2020. The impact of mobile e-commerce on GDP: A comparative analysis between Romania and Germany and how covid-19 influences the ecommerce activity worldwide. Informatica Economica, 24(2): 27-41.

Paul, J., \& Rosado-Serrano, A. 2019. Gradual internationalization vs born-Global/International new venture models. International Marketing Review, 36(6): 830-858.

doi: $\mathrm{http}$ ///dx.doi.org.ezproxy.haagahelia.fi:2048/10.1108/IMR-10-2018-0280

Rahayu, R., \& Day, J. 2017. E-commerce adoption by SMEs in developing countries: Evidence from Indonesia. Eurasian Business Review, 7(1): 25-41.

Reason, P. \& Bradbury H. eds. 2009. The SAGE Handbook of Action Research, Participative Inquiry and Practice. 2nd Ed. Sage London.

Rennie, M.W. 1993. Global Competitiveness: Born Global. McKinsey Quarterly, 4: 45-52.

Saeed, M., Tuomisto, V., \& Salluzzi, E. 2017. Unlocking the potential of digital trade. International Trade Forum, (2): 32-33.

Sanchez-Torres, J., \& Juarez-Acosta, F. 2019. Modelling SME e-commerce with IMAES. The Journal of Business \& Industrial Marketing, 34(1): 137-149.

Schu, M., Morschett, D., \& Swoboda, B. 2016. Internationalization speed of online retailers: A resource-based perspective on the influence factors. Management International Review, 56(5): 733-757.

Westerlund, M. 2020. Digitalization, Internationalization and Scaling of Online SMEs. Technology Innovation Management Review, 10(4): 48-57.

http://doi.org/10.22215/timreview/1346

Vilkas Inc. 2020. Verkkokauppaindeksi (2020) eCommere Index (in Finnish only). Retrieved from: https://www.vilkas.fi/verkkokauppaindeksi

Witkowski, K., Koralewska, M., \& Huk, K. 2020. Logistics models in E-commerce. Vedecké Práce Materiálovotechnologickej Fakulty Slovenskej Technickej Univerzity v Bratislave so Sídlom v Trnave, 28(46): 90-97.

Youn, S. 2009. Determinants of online privacy concern and its influence on privacy protection behaviors among young adolescents. The Journal of Consumer Affairs, 43(3): 389-418.

Zott, C., \& Amit, R. 2017. Business model innovation: How to create value in a digital world. GfK Marketing Intelligence Review, 9(1): 18-23.

\section{About the Authors}

Marko Mäki, Lic.Sc.(econ), Principal Lecturer, Haaga-Helia University of Applied Sciences, Finland

Lic. Sc. (Econ) Marko Mäki is currently working as a Principal Lecturer (marketing \& service development) at Haaga-Helia University of Applied Sciences, Finland. His main areas of expertise and research interests are in service concept and process development, service design and servicescape development issues in service management as well as in digital channels. Marko has been involved in Ecommerce development and research projects for the last 10 years and has published several research and conference papers on this theme.

Tuija Toivola, Ph.D, R\&D Manager, Haaga-Helia University of Applied Sciences, Finland

Tuija Toivola Ph.D. is currently working as an $R \& D$ manager at Haaga-Helia University of Applied Sciences in Finland. Her main areas of expertise are business models, business networks, digital services, and the sharing economy. Tuija Toivola has over 15 years experience in $R \& D$ activities as a project leader and developer of new business concepts. In addition, she has worked as a business consultant and speaker at business seminars and training programs. She completed her Ph.D. in business networks and strategic partnerships at the University of Vaasa in 2005. She has a Master of Science in marketing from the Turku School of Economics. Tuija has published two books, several articles and conference papers, and also has a certificate in vocational teacher education.
Citation: Mäki, Marko \& Toivola, Tuija. Global Market Entry for Finnish SME eCommerce Companies. Technology Innovation Management Review, 11(1): 11-21.

http://doi.org/10.22215/timreview/1413

(cc) BY

Keywords: Digital disruption, eCommerce, internationalization, university cooperation, Global eCom 